\title{
ECONOMICS OF PALM OIL PRODUCTION IN NSUKKA LOCAL GOVERNMENT AREA, ENUGU STATE, NIGERIA
}

\author{
Chinedum J. Chiemela ${ }^{1 *}$, Ikenna C. Ukwuaba ${ }^{1}$, Ocheje E. Ugbede ${ }^{2}$, Justina Ibe ${ }^{1}$ and Chris \\ N. Onyekwe ${ }^{1}$ \\ ${ }^{1}$ Department of Agricultural Economics, University of Nigeria Nsukka \\ ${ }^{2}$ Department of Agricultural Education, Kogi State College of Education, Ankpa, Nigeria. \\ Corresponding author email: chinedum.chiemela@unn.edu.ng
}

\begin{abstract}
With the increasing technological advancement and adoption in palm production, this study examined the economic viability of palm oil production in Nsukka Local Government Area (LGA) of Enugu state. Specifically, the study determined the socioeconomic characteristics of palm oil producers, different production techniques adopted, costs and return and the constraints that mitigate palm oil production of the farmers. Primary data were collected with the aid of a well-structured questionnaire from 50 palm oil producers selected randomly from the population. Data were analyzed using descriptive statistics, and gross margin model. In addition to the use of traditional production techniques, producers were identified to be using machine for their production (modern technique) and a combination of both. The gross margin analysis showed that the enterprise is viable and profitable. The study identified inaccessibility of palm fruits, high cost of harvesting, unavailability of human labour, and long duration of processing as the major constraints to palm oil production. The study recommended among others that producers need to form groups in other to be able to purchase modern machines as this will help in their production and also improve the rural infrastructures as it will help to reduce the transportation and the high cost of production challenges faced by farmers especially palm oil farmers/producers in Nsukka LGA of Enugu State.
\end{abstract}

Keywords: Production, Economics, Modern and Traditional Techniques.

https://dx.doi.org/10.4314/jafs.v19i1.6

\section{INTRODUCTION}

The economic importance of palm oil as a high yielding source of edible oil has placed the oil palm as one of the most important ingredients in local food production (Basiron, 2002). The extensive development of palm oil industries in many countries in the tropics has been motivated by its extremely high potential. United States Development Agency (USDA, 2020) reported that oil palm gives the highest yield of oil per unit area compared to any other oil crop and produces 
Journal of Agriculture and Food Sciences

Volume 19 Number 1, April 2021 pp 78-88
Chiemela, C.J., Ukwuaba, I.C., Ugbede, O.E.,

Ibe, J. and Onyekwe, C.N. two distinct oils such as palm oil and palm kernel oil both of which are important in World Trade. The increasing demand for vegetable oil is a worldwide phenomenon and oil palm contributes significantly to the global supply of edible oils. Oil palm produces up to ten times more oil per unit area than other oilseed crops (Murphy, 2020). In 2018, Palm oil accounted for $40 \%$ of global fats, $10 \%$ polyunsaturated fat and it has overtaken soybean oil as the most important vegetable oil used in the world (Murphy, 2020).

Palm oil production is a major source of income and employment to a large proportion of the poor rural farmers in Nigeria (Okemini, 2004). In recent times, its production has drastically reduced. This situation has been brought about by a number of socio-economic and political factors along with the technological knowhow in the industry. Factors responsible for this decline are the technical and productive inefficiency that exists in the production system for palm oil (Ukpabi, 2004). Such inefficiencies arise from high cost of labour, lack of linking roads for transportation, electricity, water, inadequate credit facility and lack of improved equipment for production (Oyaide, 2004).

According to Onwubuya (1997), about $90 \%$ of palm oil production is done using traditional techniques. The traditional methods of producing palm oil are very tedious and laborious and it requires substantial proportion of labour force. The partial adoption of high-tech mills by the palm oil producers is a welcome step in the right direction. Though it is capital intensive; however, it ensures increased efficiency in palm oil extraction and high-quality palm oil (Ojo, 2002). The production of palm oil using the modern techniques comprises crushing the kernels into small particles, boiling and extracting oil using an oil seed expeller, hydraulic press or petroleum derived solvent (Omoti, 2004). The success or failure of production depends largely upon how labour and other associated resources are efficiently used (Ukpabi, 2004). An efficient production technique increases the quality and quantity of products available for consumption and trade (Okereke, 2002).

Currently the demand for palm oil in the study area, has far exceeded the production. More so, the output of palm oil production has been low as a result of outdated equipment to aid production (Olagungu, 2008). This drop in production has been attributed to indiscriminate felling of the oil palm trees without replanting. More so, the small-scale farmers who constitute the bulk of palm oil producers in the study area seemed not to be adequately assisted. Thus, they 
Journal of Agriculture and Food Sciences

Volume 19 Number 1, April 2021 pp 78-88 have continued to rely on outdated equipment. However, there is need to meet the demand of the local consumers in the area. Therefore, there is need to ascertain the viability of the palm oil production enterprise especially with the recent partial adoption of the modern technology. However, it, therefore, becomes necessary to find out the various techniques used by producers in the study area. More so there is the need to know whether the increase in revenue due to efficient production of palm oil offset the cost of production. Specifically, the study described the socio-economic characteristic of palm oil producers in the study area, described the different production techniques employed by producers, it also ascertained the cost and returns of palm oil production and finally identified the constraints that militate against palm oil production in the study area.

\section{MATERIALS AND METHOD}

\section{Study Area}

The study area is Nsukka Local Government Area in Enugu State, Nigeria. Nsukka is a town and a local government Area in South-East Nigeria in Enugu-North senatorial district.

\section{Sampling Techniques}

A multistage sampling technique was used in selecting the sample for the study. In the first stage, purposive sampling was employed in selecting five communities in Nsukka Local Government Area where palm oil production is concentrated. The towns selected were Nsukka town, IbagwaAni, Eha-Alumona, Okpuje and Opi. In stage two, 10 producers (seven traditional technique users and three modern technique users) each were randomly selected, making a total of 50 respondents (35 traditional technique users and 15 modern technique users). Data were obtained through the use of questionnaires which were administered by the researcher. The data were analysed using gross margin analysis and descriptive statistics such as Frequency, Percentage and Mean. A four-point Likert-type scale was used to collect information from the respondents. The rating was designed thus: Strongly agree $(\mathrm{SA})=4$, agree $(\mathrm{A})=3$, disagree $(\mathrm{D})=2$, and strongly disagree $(\mathrm{SD})=1$. The mean score of the respondents based on the 4-point scale was $4+3+2+1=1010 / 4=2.50$. Using the interval scale of 0.05 , the upper limit cut-off point was $2.50+0.05=2.55$. The lower limit was $2.50-0.05=2.45$. Based on these, any mean score below 2.45 (i.e., MS<2.45) was regarded as not important. Those between 2.45 and 2.55 was 
Journal of Agriculture and Food Sciences

Volume 19 Number 1, April 2021 pp 78-88 considered as agree (ie. $2.45<2.55)$. A mean score greater than 2.55 (MS $>2.55$ ) was considered strongly agree.

The gross margin model was expressed as follows:

$\mathrm{GM}=\mathrm{TR}-\mathrm{TVC}$

Where:

$\mathrm{GM}=$ Gross margin

$\mathrm{TR}=$ Total revenue

$\mathrm{TVC}=$ Total variable cost

$\mathrm{BCR}=\mathrm{TR} / \mathrm{TVC}(\mathrm{BCR}>1$ is profitable $)$
Chiemela, C.J., Ukwuaba, I.C., Ugbede, O.E., Ibe, J. and Onyekwe, C.N.

\section{RESULTS AND DISCUSSION}

Socioeconomic characteristics of the respondents

The result presented in Table 1 showed the socioeconomic characteristics of palm oil producers in the study area. From the result presented in Table $150 \%$ of the respondents were male while the remaining $50 \%$ were female. This showed that both the male and female respondent in the study area are actively involved in palm oil production. It further showed the respondents between 31 to 40 years were $19 \%$; 41 to 50 years were $14 \%$ while producers above 50 years were $5 \%$. The mean age was 38 years which showed that most of the producers are in their active years. This may imply that people of this age are likely to be energetic and willing to withstand the tedious work involved in palm oil production. The result presented also indicated that the percentage of palm oil producers with primary education was $24 \%$ while those with secondary education was $26 \%$. About $12 \%$ had OND/NCE while $14 \%$ and $8 \%$ of the producers had HND/degree and postgraduate respectively. The mean years of education of the producers was 6 years while only $14 \%$ had no formal education. The mean years implied that the educational background of palm oil producers in the study area was very low. The finding was in line with Onwubuya (2007) who reported that most palm oil producers had little or no formal education and also engage more in the use of the traditional method for production.

The implication could be because of the steady rural-urban migration among the educated ones. 
Journal of Agriculture and Food Sciences

Volume 19 Number 1, April 2021 pp 78-88
Chiemela, C.J., Ukwuaba, I.C., Ugbede, O.E.,

Ibe, J. and Onyekwe, C.N.

The marital status of the palm oil producers in the study area showed that $24 \%$ of the respondents were single while $60 \%$ were married. This implied that married people engage more in the enterprise; this could be because having a greater number of the labour force will help reduce the labour intensity of the enterprise

From the result presented in Table 1 also shows that palm oil producers with three household members were $30 \%$, the producers with four to six household sizes were $58 \%$ while those producers above six members were $12 \%$. The mean household size was four persons. This implies that the producers have a sizeable household size which is vital in increasing the family labour force and reducing the labour cost. The monthly income of palm oil producers in the study area revealed that $46 \%$ of the producers earn between N50, 000 and 20,000 monthly while $40 \%$ earned between $\mathrm{N} 51,000$ and $\mathrm{N} 10,000$. The mean monthly income of the producers was N76, 520. The result implied that an average palm oil producer earns far above the federal government national minimum wage of $\mathrm{N} 30,000$ and so, it's a good source of income and a means of livelihood especially for the rural dweller. The result of the years of experience showed that majority which constituted $70 \%$ of the producers had between 10 and two years of experience; $22 \%$ had 11 to 20 years of experience while only $8 \%$ had above 20 years of experience. The mean oil palm production experience was10 years, this implied that an average producer in the study area have attained 10 years in the oil palm production.

\section{Production Techniques used by the Respondents}

The result presented in Table 2 showed the different techniques used by the respondents in oil palm production. The Table showed that $32 \%$ of the respondents use the traditional production technique, $20 \%$ uses the modern production technique while $48 \%$ uses a combination of traditional and modern production techniques. The traditional technique is adopted because it is cost-effective while the modern production technique is adopted because it saves time. Traditional production technique and modern production technique were the production types identified in the study area. Two methods of fruit maceration are common in traditional processing: pounding cooked/soaked fruits in large wooden or concrete mortars with a wooden pestle and foot trampling the cooked but cold fruits in canoes or specially constructed wooden troughs. 
Journal of Agriculture and Food Sciences

Volume 19 Number 1, April 2021 pp 78-88
Chiemela, C.J., Ukwuaba, I.C., Ugbede, O.E

Ibe, J. and Onyekwe, C.N.

The modern production technique involves the production of crude palm oil using a large set of equipment, which can range from crude, manual mechanisms to advanced automated machinery. Table 2 shows that $70 \%$ of the respondents use the traditional production method while $30 \%$ of them uses the modern production technique. This implied that the majority of palm oil producers in the study adopts the traditional production technique as their preferred method of production.

Lack of capital, high level of yield and or a combination of both reasons were the major determinants of the choice of the production type used by the respondents. Twenty percent of the respondents indicated that shortage of capital was the motive for using a particular production method, $16 \%$ was because of high yield produced while $14 \%$ indicated both lack of capital and high yield informed their decision on the production method used.

\section{Costs and Returns of Palm Oil Production}

The mean monthly costs and returns of palm oil production using traditional and modern techniques are shown in Table 3. The Table showed that the mean selling price of a litre of palm oil was $\mathrm{N} 660.5$ The total variable cost of palm oil production was $N 30,588$. The gross margins for traditional and modern methods were $\mathrm{N} 54,857$ and $\mathrm{N} 22,018.35$ respectively. The results indicated that the enterprise was very viable. The high benefit-cost ratios of 3.41 and 1.52 for traditional and modern techniques further affirmed the viability of the enterprise. The high ratios could be attributed to the fact that most of the producers inherited the oil palm trees and as such did not incur cost in procuring the palm fruits or oil palm tree. Also, the result showed that cost of machine processing of the palm fruits contributed $65 \%$ of the total variable cost of production of palm oil production using the modern method in the study area. The high cost of the modern processing negatively affected the profit margin of the enterprise.

\section{Constraints of Palm Oil Producers}

The result presented in Table 4 showed the distribution of the various constraints that mitigate palm oil production in the study area. The major constraints to palm oil production in the study area were inaccessibility of palm tree (2.90), high cost of harvesting (2.48), and unavailability of human labour (2.62) and long duration of processing (2.66). The result implied that the variables stated above were the major factors that led to inefficiency and decreased viability of the enterprise. The more their influence, the less the viability of the enterprise. However, high level 
Journal of Agriculture and Food Sciences

Volume 19 Number 1, April 2021 pp 78-88

of skill (2.18), unavailability of market (2.40), deterioration of produce (1.92) and lack of storage

study area. This implies that these variables were not significant enough to influence the viability of the palm oil production negatively.

\section{CONCLUSION}

Palm oil, in addition to cocoa, rubber, groundnut was among the important cash crop and mainstay of Nigerian economy especially in pre oil era. It is one of the major sources of livelihood in most rural areas and semi urban areas of Southern Nigeria. Both male and female; young and old were involved in the oil palm production in Nsukka LGA of Enugu state. Palm oil production technique could either be through the traditional production technique or modern method through the use of machines. Even though the use of the machine is faster and easier, most of the producers still adopt the traditional production technique as a means of production because this technique appears to be more affordable and cost-effective, though laborious. The enterprise was very viable in the study area in spite of the numerous constraints such as high cost of harvesting, long-duration during production, lack of storage facility, unavailability of labour, deterioration of produce, unavailability of market

The study therefore, recommends that producers need to form groups such as cooperatives towards the acquisition, establishment and installation of palm oil processing machines or plants at different strategic areas in Nsukka LGA. This would enable most palm oil producers to adopt the modern technique at a lower cost. This will lead to increased production efficiency in the industry. 
Journal of Agriculture and Food Sciences

Volume 19 Number 1, April 2021 pp 78-88

\section{REFERENCES}

Basiron, J. (2002). Palm Oil and its Global Supply and Demand prospects. Oil palm industry. Econ. J. 2(1): 3.

Murphy, D.J. (2020). Palm oil: Scourge of the earth or wonder crop. United Nation Food and Agriculture and Malaysian Palm Oil board. Working paper.

Okafor, N. P (1998). Economics of palm oil marketing in Ibadan North L.G.A. of Oyo State, Nigeria. http://Ajol.info/index.php/joten/index. Accessed on 3 June 2009.

Okemini, J. (2004). Government policy on oil palm development in Nigeria. Analytical review and policy options. Paper presented at National Conference on oil palm industrial Revolution in Nigeria, Benin City.

Okereke, P. F (2002). Processing of palm oil in South Western Nigeria. Int. J. Agricultural Econ. Rural Devpt., 1(2): 69 - 77

Olagungu, F.I. (2008). Economics of palm oil processing in south western Nigeria. Int. J. Agric. Econs. Rural development. 1(2). 69-77.

Omoti, I. U. (2001). The Future of the oil industry in Africa and Strategies for Development. The Nigerian situation.

Omoti, U. (2004). Problems and prospects of oil palm Development processing and potentials in Nigeria. A paper prepared for African Investment and Development Agency conference on attracting private foreign investment into Nigeria's oil palm industry, Kuala Lumpur, December, 2004.

Onwubuya, I. (1997). Oil palm development in Nigeria with particular reference to the Southeast Agro ecological zone. Invited paper read at the workshop on eco-regional programme for the humid and sub-humid tropics of sub-Saharan Africa. Imo Concorde Hotel, Owerri. Nigeria.

Oyaide, O. F. (2004). Presidential road map on Vegetable Oil Production in Nigeria, Presco plc.

Ukpabi, U. (2004). Sustainable Post Harvest Technologies for the major food crop and flesh. A paper presented at the workshop for Abia State Local Government Agricultural Officers, Umudike, $10^{\text {th }}-12^{\text {th }}$ may, pg 1-3. 
Journal of Agriculture and Food Sciences

Volume 19 Number 1, April 2021 pp 78-88
Chiemela, C.J., Ukwuaba, I.C., Ugbede, O.E.,

Ibe, J. and Onyekwe, C.N.

Table 1: Socioeconomic characteristics of palm oil producers

\begin{tabular}{|c|c|c|c|}
\hline Item option & Frequency & Percentage & Mean \\
\hline \multicolumn{4}{|l|}{$\overline{\operatorname{Sex}}$} \\
\hline Male & 25 & 50 & \\
\hline Female & 25 & 50 & \\
\hline Total & 50 & 100 & \\
\hline \multicolumn{4}{|l|}{ Age } \\
\hline 30 years and below & 12 & & 38.24 \\
\hline 31 to 40 years & 19 & & \\
\hline 41 to 50 years & 14 & & \\
\hline Above 50 years & 5 & & \\
\hline Total & 50 & 100 & \\
\hline \multicolumn{4}{|l|}{ Education } \\
\hline No formal education & 7 & 14 & 6.56 \\
\hline Primary education & 12 & 24 & \\
\hline Secondary education & 13 & 26 & \\
\hline OND/NCE & 6 & 12 & \\
\hline HND/Degree & 7 & 14 & \\
\hline Postgraduate & 4 & 8 & \\
\hline Adult education & 1 & 2 & \\
\hline Total & 50 & 100 & \\
\hline \multicolumn{4}{|l|}{ Marital status } \\
\hline Single & 12 & 24 & \\
\hline Married & 30 & 60 & \\
\hline Divorced/separated & 4 & 8 & \\
\hline Widowed & 4 & 8 & \\
\hline Total & 50 & 100 & \\
\hline \multicolumn{4}{|l|}{ Household size } \\
\hline 3 and below household members & 15 & 30 & 4.42 \\
\hline 4 to 6 household members & 29 & 58 & \\
\hline Above 6 household members & 6 & 12 & \\
\hline Total & 50 & 100 & \\
\hline \multicolumn{4}{|l|}{ Monthly income } \\
\hline N50000 and below & 23 & 46 & $\mathrm{~N} 76520.0$ \\
\hline $\mathrm{N} 51000$ to $\mathrm{N} 10000$ & 20 & 40 & \\
\hline Above $\mathrm{N} 100000$ & 7 & 14 & \\
\hline Total & 50 & 100 & \\
\hline \multicolumn{4}{|l|}{ Years of Experience } \\
\hline 10 years and below & 35 & 70 & 10.10 \\
\hline 10 to 20 years & 11 & 22 & \\
\hline 20 to 30 years & 4 & 8 & \\
\hline Total & 50 & & \\
\hline
\end{tabular}

Source: Field survey, 2018 
Journal of Agriculture and Food Sciences

Volume 19 Number 1, April 2021 pp 78-88

Table 2: Production techniques

\begin{tabular}{lll}
\hline & Frequency & Percentage \\
\hline Production Technique Used & & \\
Traditional production technique & 16 & 32.0 \\
Modern production technique & 10 & 20.0 \\
Both traditional and modern production technique & 24 & 48.0 \\
Production Method Mostly Used & & \\
Traditional production technique & 35 & 70.0 \\
Modern production technique & 15 & 30.0 \\
Reason for the Use of the Method & & \\
Lack of capital & 20 & 40.0 \\
Gives high level of yield & 16 & 32.0 \\
Both & 14 & 28.0 \\
\hline Source:
\end{tabular}

Chiemela, C.J., Ukwuaba, I.C., Ugbede, O.E., Ibe, J. and Onyekwe, C.N.

Source: Field survey, 2018

Table 3a: Cost and Returns of Palm Oil Production (Traditional method)

\begin{tabular}{|c|c|c|c|c|}
\hline Items & quantity & Price/unit & Value ( & $\%$ share of total cost \\
\hline Revenue & 107.4litres & 660.5 & $70,937.7$ & \\
\hline Palm Oil & & & & \\
\hline \multicolumn{5}{|l|}{ Variable Cost (VC) } \\
\hline Harvesting of Palm fruits & & & 7,350 & 0.46 \\
\hline Manual processing & & & 4397 & 0.27 \\
\hline $\begin{array}{l}\text { Other expenses (Transportation, } \\
\text { water, firewood) }\end{array}$ & & & 4333.7 & 0.26 \\
\hline TVC & & & $16,080.7$ & \\
\hline GM =TR-TVC & & & 54,857 & \\
\hline Benefit Cost Ratio & & & 3.41 & \\
\hline
\end{tabular}

Source Field Survey, 2018

Table 3b: Cost and Returns of Palm Oil Production (Modern method)

\begin{tabular}{|c|c|c|c|c|}
\hline Items & quantity & Price/unit & Value (丹) & $\%$ share of total cost \\
\hline Returns & 55.3litres & 660.5 & $36,525.65$ & \\
\hline Palm Oil & & & & \\
\hline Variable Cost (VC) & & & & \\
\hline Harvesting of Palm fruits & & & 3,150 & 0.22 \\
\hline Machine Processing & & & 9,500 & 0.65 \\
\hline $\begin{array}{l}\text { Other expenses (Transportation, } \\
\text { water, firewood) }\end{array}$ & & & $1,857.3$ & 0.12 \\
\hline TVC & & & $14,507.3$ & \\
\hline GM $=$ TR-TVC & & & $22,018.35$ & \\
\hline Benefit Cost Ratio & & & 1.52 & \\
\hline
\end{tabular}

Source Field Survey, 2018 
Journal of Agriculture and Food Sciences

Volume 19 Number 1, April 2021 pp 78-88
Chiemela, C.J., Ukwuaba, I.C., Ugbede, O.E., Ibe, J. and Onyekwe, C.N.

Table 4: Constraints to palm oil production

\begin{tabular}{llll}
\hline Constraint & Mean & Standard Dev. & Decision \\
\hline Inaccessibility of palm tree & 2.90 & 0.91 & Major constraint \\
High cost of harvesting & 2.48 & 0.86 & Major constraint \\
Unavailability of human labour & 2.62 & 0.92 & Major Constraint \\
Long duration of processing & 2.66 & 0.96 & Major constraint \\
High level of skill needed & 2.18 & 0.94 & Minor constraint \\
Unavailability of markets & 2.40 & 1.16 & Minor constraint \\
Deterioration of produce & 1.92 & 0.83 & Minor constraint \\
Lack of storage facility & 2.32 & 0.89 & Minor constraint \\
\hline
\end{tabular}

Source: Field Survey, 2018 